\title{
Pandemien utfordrer sykepleieetikken
}

Sykepleiere har arbeidsdager i konstant skvis mellom smittevern og forsvarlig helsehjelp. Det er en vanskelig balansegang.

\section{Berit Liland}

Intensivsykepleier og medlem av Rådet for sykepleieetikk

Akershus universitetssykehus

Etikk

Pandemi

Sykepleien 2021109 (87791) (e-87791)

DOI: 10.4220/Sykepleiens.2021.87791

Jeg går litt tilbake i tid, til midten av februar 2021, når vi er i starten av tredje bølge av pandemien. Det er fredag ettermiddag, og jeg er på seinvakt ved en av landets største intensivavdelinger. Vi er allerede på bristepunktet av hva vi kan håndtere.

Jeg tar imot rapport om pasienten jeg skal ha ansvaret for. Pasienten, en mann i 6oårene, har akkurat ankommet, han ventet i det lengste før han tok kontakt med helsevesenet. Kanskje var det kona som ringte 113?

Da ambulansen hentet ham, var han knapt ved bevissthet. Nå legges han i kunstig koma. Han får neppe med seg ordene mine: «Du er på sykehus, vi tar vare på deg.» Det legges inn venekateter, arteriekateter, urinkateter, det tas blodprøver og røntgen. Vi jobber i dyp konsentrasjon, vi redder liv.

\section{Pårørende får ikke komme på besøk}

Under normale omstendigheter er ivaretakelse av pårørende en viktig del av gjøremålene våre. Denne ettermiddagen skulle noen ha sittet på pårørenderommet nederst $\mathrm{i}$ korridoren, ventende på å få komme inn. 
Kanskje har de tatt med bilder av pasienten de skal bes $\varnothing$ ke. Bilder som forteller en historie, som sier oss noe om hvem pasienten i senga er, siden han selv ikke er i stand til det. Kanskje har de med tegninger fra barn eller barnebarn - som forankrer pasienten til verdenen utenfor sykerommet.

Kona til pasienten jeg har ansvaret for, skulle også vært blant dem som venter på pårørenderommet. Jeg skulle ha gått inn til henne, informert om behandlingen mannen hennes får, forberedt henne på hva som møter henne når hun kommer inn på rommet: respirator, tube i munnen, intravenøsslanger, ledninger og alarmer. Det blir bare en samtale på telefonen, hun får ikke komme på bes $\varnothing$ k. Hun er i karantene, og det er bes $\varnothing$ ksrestriksjoner.

Det blir en kort natt, og lørdag morgen er jeg tilbake hos pasienten som kom inn i går. Han skal legges over i mageleie for å ventilere alle delene av lungene, det er mye som skal ordnes og organiseres.

\section{Vi må også tenke på neste pasient}

Sykepleieren hos pasienten ved siden av får beskjed om å gjøre sin pasient klar for overflytting til en annen intensivavdeling ved et annet sykehus. Pasienten, en dame på min alder, måtte tilkoples respirator etter noen dager med maskebehandling.

Hun ville helst ikke, hun var redd, og hun var tapper, ville så gjerne komme seg gjennom uten respiratorbehandling. Nå ligger hun i kunstig koma, tilkoplet respirator, snart på vei til et annet sykehus. Vi må skaffe ledig plass. Ikke fordi noen venter på tur, men for å ha kapasitet til den neste som måtte trenge respirator.

\section{«Følelsen av mismot når meg idet jeg trasker ned trappene til garderoben.»}

$\AA$ organisere og klargjøre for intensivtransport tar tid, det er mange som er involvert i prosessen. Når neste pasient er på vei opp fra akuttmottaket, er det for sent å organisere transport. Det blir en travel vakt, vi må holde fokus, vi jobber intensivt med begge pasientene.

Følelsen av mismot når meg idet jeg trasker ned trappene til garderoben. Er det god behandling å transportere alvorlig syke pasienter?

\section{Sykepleiere går på akkord med forsvarlig helsehjelp}


Historien min fra en helg på intensiv i februar 2021 viser noen av de etiske utfordringene sykepleiere har stått i gjennom pandemien. Knappe ressurser, lav bemanning og liten eller ingen tid til faglig og etisk refleksjon fører til at mange sykepleiere går på akkord med det de mener vil være god omsorg og forsvarlig helsehjelp.

Intensivsykepleier Rita Paulsen ved intensivavdelingen i Troms $\varnothing$ forteller at det høye arbeidspresset gjør at de ikke får snudd respiratorpasientene så ofte som de burde (1).

\section{«Mange sykepleiere har måttet håndheve regler som ikke tar individuelle hensyn.»}

Mange sykepleiere har måttet håndheve regler som ikke tar individuelle hensyn, og særlig utfordrende har det vært med besøksstans og sosial isolering. Rådet for sykepleieetikk har fått flere henvendelser både fra pårørende og sykepleiere med fortellinger om hvor vanskelig det har vært å følge restriksjonene. Det har også blitt stilt spørsmål om hvorvidt reglene har vært for strenge.

Frisk eller syk - vi ønsker alle å være sammen med dem som står oss nærmest, kanskje særlig i krisetider. De som gir oss trygghet og forankrer oss til livet. For noen har kanskje ensomhet og isolasjon bidratt til sykdom eller forverring av sykdom.

\section{Helsepersonell står i skvis}

Dette er et eksempel på helsepersonellets skvis i pandemien: Vi skal følge strenge smittevernregler, samtidig som vi skal gi faglig forsvarlig og omsorgsfull hjelp. Det er en vanskelig balansegang, for vi har også en plikt til å ta vare på de mest sårbare - de av oss som trenger ekstra beskyttelse.

Høstens smitteutbrudd på sykehjem og sykehusavdelinger, til tross for at mange er vaksinerte, er en påminnelse om den utryggheten vi fortsatt befinner oss i.

Våre yrkesetiske retningslinjer sier følgende: «Sykepleieren ivaretar den enkelte pasients verdighet og integritet, herunder retten til faglig forsvarlig og omsorgsfull hjelp, retten til å være medbestemmende og retten til ikke å bli krenket» (2).

\section{«Vi vet at vi må ha beredskap for de neste syke som kommer. Vi gjør vår plikt.»}


Vi som jobbet sammen på intensivavdelingen «min» lørdagen i februar, visste hva som var denne respiratorpasientens beste. Det var ikke transport til et annet sykehus. Men hva var alternativet?

Magefølelsen settes til side, vi jobber samvittighetsfullt på alle kanter, tar vare på dem som allerede ligger her, dem som skal transporteres til et annet sykehus, og vi gjør klart til neste pasient. Vi vet at vi må ha beredskap for de neste syke som kommer. Vi gjør vår plikt.

\section{Pandemien preger fortellingen}

Min fortelling er preget av pandemien. Mange sykepleiere opplever arbeidsdager i konstant skvis, også når hverdagen er normal.

Nå kommer det flere fortellinger fra sykepleiere i kjølvannet av pandemien, men det som beskrives, er en normaltilstand. Maria Fallsen skriver i et innlegg $\mathrm{i}$ Aftenposten at hun er sliten av å beklage for alt hun ikke får gjort. Hun forteller om en vakt der hun bidro til å redde liv, men hadde dårlig samvittighet for alt det andre hun ikke fikk gjort (3).

At kapasiteten i helsevesenet er for liten, er ikke noe nytt. Pandemien kommer på toppen av et allerede presset helsevesen. Vi mangler sykepleiere og helsefagarbeidere med fagkunnskaper, skriver Isachsen-Hagen og Lilleb $\varnothing$ i en kronikk i Adresseavisen. (4).

Tiden med pandemi har tydeliggjort hvordan knapphet på menneskelige ressurser utfordrer etikken generelt i helsevesenet. Det håper jeg sykepleiere fortsetter å snakke høyt om.

\section{Referanser}

1. NTB. Stort press på intensivavdelingen på UNN. Nettavisen.. 13.11.2021. Tilgjengelig fra: https://www.nettavisen.no/nyheter/innenriks/stort-press-paintensivavdelingen-pa-unn/s/12-95-3424204969 (nedlastet 02.12.2021).

2. Norsk Sykepleierforbund (NSF). Yrkesetiske retningslinjer. Oslo: NSF; u.å. Tilgjengelig fra: https://www.nsf.no/sykepleiefaget/yrkesetiske-retningslinjer (nedlastet 02.12.2021).

3. Fallsen M. Jeg er sykepleier, og jeg er sliten. Av å beklage. Aftenposten. 02.11.2021. Tilgjengelig fra:

https://www.aftenposten.no/meninger/debatt/i/5GWkem/jeg-er-sykepleier-og-jeger-sliten-av-aa-beklage (nedlastet 02.12.2O21). 
4. Isachsen-Hagen M, Lilleb $\varnothing \mathrm{G}$. Vi har deg, men alt har en grense. Adresseavisen. 12.11.2021. Tilgjengelig fra:

https://www.midtnorskdebatt.no/meninger/kronikker/2021/11/12/Vi-har-deg-menalt-har-en-grense-24802595.ece (nedlastet 02.12.2021). 